\title{
Effect of Study Skills Program Participation on Undergraduate Student Academic Performance
}

\author{
John Jordan ${ }^{1}$, Mitch Parker ${ }^{1}$, Xiaohong Li $^{1} \&$ Anthony J Onwuegbuzie ${ }^{1, *}$ \\ ${ }^{1}$ Department of Educational Leadership, Box 2119, Sam Houston State University, Huntsville, \\ Texas 77341-2119, USA \\ *Corresponding author: Department of Educational Leadership, Box 2119, Sam Houston \\ State University, Huntsville, Texas 77341-2119, USA. E-mail: tonyonwuegbuzie@aol.com
}

Received: January 9, 2015 Accepted: February 28, 2015 Published: March 30, 2015

doi:10.5296/ije.v7i1.6888 URL: http://dx.doi.org/10.5296/ije.v7i1.6888

\begin{abstract}
Using archived data spanning from 2004 to 2010 from a large, public, Texas university's formal study skills program, the relationships between program participation and grade point averages (GPAs), 1-year retention rates, and graduation rates (i.e., they did or did not graduate) were analyzed. Employing a proportionate stratified random sampling scheme within a causal-comparative research design, the authors conducted an independent samples $t$ test and chi-square tests - after applying the Bonferroni adjustment to control for inflations of Type I error - to investigate the differences between the experimental group $(n=2,074)$ and control group $(n=2,074)$ with respect to these three outcome measures (i.e., GPAs, 1-year retention rates, and graduation rates). Findings indicated a small but statistically significant difference in GPA between students in the experimental group and the control group. However, no statistically significant difference in retention rates emerged between students in these two groups. Finally, although a statistically significant difference emerged in graduation rates between students in these two groups, the effect size was negligible. As such, further research is suggested.
\end{abstract}

Keywords: Study Skills, Academic Performance, Student Success, Graduation Rates, Retention 
In the 1990s, the United States led the world in higher education graduation rates (Abel, 2000). However, almost two decades later, the United States ranked 16th in the world in college graduates (Chalian, 2012). This drop in rankings has had a negative effect on the United States' political, social, and economic standings, prompting U.S. President Barack Obama to issue a mandate to the U.S. educational system to regain its place at the forefront of the world's higher education graduation rates by 2020 (Johnson, 2010). Due to this call-to-arms, community colleges and universities across the United States are searching for methods to boost retention and graduation rates.

This push to excel in education has led to an increase in the research of methods and strategies to boost students' academic understanding and to improve their success (e.g., graduation) rates. Research has shown that programs and methodologies designed to aid in the development and improvement of students' study skills can lead to an increase in academic success (Kartika, 2007; Proctor, Prevatt, Adams, \& Reaser, 2006; Robyak, 1978; Sanoff, 2006; Urciuoli \& Bluestone, 2013). Many researchers have advocated study skills because of the positive relationship between success in college and students' knowledge of and ability to apply study skills (Al-Hilawani \& Sartawi, 1997; Crede \& Kuncel, 2008; Kartika, 2007; Larose \& Roy, 1991; Metzner \& Bean, 1987). Supporting this connection, a recent meta-analysis, conducted by Crede and Kuncel (2008), indicated that study skills were not only an important predictor of academic success in higher education, but rivaled grade point average (GPA) and standardized test scores, such as the Scholastic Aptitude Test (SAT), in predicting student success. Although many students might learn these study skills on their own, many more will go through school without acquiring any effective study skills (Nicaise \& Gettinger, 1995).

As identified by Crede and Kuncel (2008), several authors have agreed that study skills have a positive effect on students' academic success (i.e., GPA) and self-perception. However, there appears to be a gap in the literature. Researchers have examined the influence of study skills on GPA and self-perception by means of self-study or classroom inclusion (e.g., Al-Hilawani \& Sartawi, 1997; Crede \& Kuncel, 2008; Kartika, 2007), but only rarely have they assessed the efficacy of formal study skills programs. Moreover, in these previous studies, the researchers typically limited their analyses of effectiveness to semester GPA, overall GPA, and/or retention rates (Al-Hilawani \& Sartawi, 1997; Kartika, 2007; Urciuoli \& Bluestone, 2013). This trend has created a vacuum in the literature concerning the analysis of the influence of study skills on graduation rates.

The purpose of the current study, then, was an attempt to address this gap in the literature by examining the difference in academic performance between undergraduate students enrolled at a Texas, public university who participated in a study skills program and those students who did not. Specifically, the authors investigated the relationships between program participation and GPA, retention rates, and graduation rates. It was hoped that scrutinizing these relationships would inform university administrators and educators as they research programs that can assist in increasing students' academic performance in the form of graduation rates, retention rates, and GPAs. 
The following research questions were addressed: (a) What is the difference in GPA between undergraduate students who participated in a study skills program and undergraduate students who did not participate in a study skills program?; (b) What is the difference in retention rates between undergraduate students who participated in a study skills program and undergraduate students who did not participate in a study skills program?; and (c) What is the difference in graduation rates between undergraduate students who participated in a study skills program and undergraduate students who did not participate in a study skills program?

The data analysis was approached based on the following three hypotheses: (a) There is a difference in GPA between undergraduate students who participated in a study skills program and undergraduate students who did not participate in a study skills program; (b) There is a difference in retention rates between undergraduate students who participated in a study skills program and undergraduate students who did not participate in a study skills program; and (c) There is a difference in graduation rates between undergraduate students who participated in a study skills program and undergraduate students who did not participate in a study skills program.

These non-directional hypotheses were based primarily on two theoretical frameworks: the theory of student involvement (Astin, 1984, 1999) and the theory of student departure (Tinto, 1993). According to Astin's $(1984,1999)$ theory of student involvement, students who learn the most are the ones who are most involved in both the academic and social aspects of the college experience (i.e., the amount of psychological and physical energy devoted to the collegiate experience). Astin (1999) defined an engaged student as one who spends considerable time and energy on her/his scholastic pursuits, devoting both time and energy in student organizations, and has valuable interactions with faculty. In contrast, Tinto's (1993) theory of student departure centered upon the idea that the efforts and involvement of students in the academic process affected their matriculation and, thus, retention rates, at educational institutions. Also, he argued that the addition of student services could positively influence student retention. Both of these theories support the assumption that academic programs, such as the study skills program, which boost students' abilities to learn and to apply knowledge more effectively can, in turn, increase students' involvement in their academics and the college experience, thereby increasing retention.

\section{Literature Review}

Researchers have analyzed study skills and their influence on student performance for more than a century (Moore, Readance, \& Rickleman, 1983; Richardson, Robnolt, \& Rhodes, 2010). The consensus has been that study skills has had not only a positive influence on academic performance, but also has served as an integral component of individual and institutional success (Crede \& Kuncel, 2008; Richardson et al., 2010; Tinto, 1993). Moreover, students who developed and applied study skills became more engaged in academics, thereby increasing their levels of academic performance (Kartika, 2007; Proctor et al., 2006; Robyak, 1978; Sanoff, 2006; Urciuoli \& Bluestone, 2013). This increase in student engagement corresponds with Astin's $(1984,1999)$ theory of involvement, which postulates that students 
who learn the most are the ones who expend greater amounts of psychological and emotional energy.

Furthermore, previous researchers in the area of study skills have advocated the use of study skills via classroom instruction as well as specialized programs to improve academic performance, thereby increasing retention in higher education (Al-Hilawani \& Sartawi, 1997; Kartika, 2007; Urciuoli \& Bluestone, 2013). Like Astin, Tinto (1993) argued that students who were more involved in the educational process performed better in school than did those who were less involved. Additionally, Tinto (1993) contended that this increase in engagement would positively affect student retention in educational institutions; therefore, these institutions would benefit from increased support services.

\section{Study Skills}

History of study skills. In the early 1900s, the acquisition and use of study skills, primarily in the form of reading and note-taking skills, were important issues for U.S. educators (Moore et al., 1983). Although this focus on reading and comprehension continued until the 1940s, new research on learning skills comprehension became almost nonexistent during the 1950s and 1960s (Tierney \& Cunningham, 1980). Starting in the 1970s and continuing into the 1980s, researchers began to identify themes within study skills that allowed students to excel (Richardson et al., 2010). The primary additions to study skills research were the inclusion of motivation, self-monitoring/regulation, and metacognition as crucial elements of effective study skills practices (Gardner, 1979; Knowles, 1975; Metzner \& Bean, 1987; Richards, 1975). During the late 1980s and 1990s, researchers shifted from emphasizing study skills in traditional environs (e.g., libraries, classrooms) to focusing on computer-based study skills (Richardson et al., 2010). However, this continued concentration on computerand web-based learning skills, although common in recent literature, did not negate the importance of traditional study skills. Instead, researchers argued that the skills used in traditional environs, such as libraries and classrooms, could be used and adapted by students for digital- and web-based activities (Eveland \& Dunwoody, 2002). Although the emphasis of study skills research has been on the individual skills themselves, there was an increase in research during the late 1990s through the 2000s that shifted focus from individual skills to the effect of these skills on academic success factors (Crede \& Kuncel, 2008).

Definition of study skills. Even though study skills have been of interest to researchers in the United States since the beginning of the 20th century, no single, universally accepted definition of study skills exists within the literature. For example, Harris and Hodges (1995) defined study skills as "the techniques and strategies that help a person read or listen for specific purposes with the intent to remember" (p. 245). Lenz, Ellis, and Scanlon (1996) distinguished between study tactics (i.e., the procedures and methods used when learning) and study strategies (i.e., the individual's method for choosing the best tactic for each learning task). According to Crede and Kuncel (2008), this distinction has been mirrored in several studies over the last 20 years. Gettinger and Seibert (2002) elaborated on this difference by asserting that study strategies are comprehensive in scope, including a person's thoughts and actions both before and during the study process. It is this difference in 
terminology that helps explain how study skills (i.e., strategies) can remain unchanged and applicable over time, whereas study behaviors (i.e., tactics) change with both the individual and environment (Richardson et al., 2010).

Effect of study skills programs. Students in all classes and all levels of education might struggle in school - not because they lack the ability to excel, but because they lack competence with study skills (Nicaise \& Gettinger, 1995). Moreover, many authors have reported a statistically significant positive relationship between study skills and the short-term elements of academic success (i.e., semester GPA and self-perception) (Al-Hilawani \& Sartawi, 1997; Crede \& Kuncel, 2008; Kartika, 2007). However, only recently have researchers shifted focus from short-term elements to more long-term elements, primarily retention rates, as indicators of academic success (Al-Hilawani \& Sartawi, 1997; Crede \& Kuncel, 2008; Kartika, 2007; Urciuoli \& Bluestone, 2013). This focus on short-term elements of academic success (i.e., GPA, self-perception) seems to have limited the scope of study skills to only one criterion of academic success, providing few studies that center upon long-term criteria. Further, the present authors could not identify any studieswherein the relationship between study skills and graduation rates was analyzed.

\section{Retention Rates}

Both politicians and university administrators are concerned with the persistence and retention of students and their acquisition of fundamental academic skills (Garton, Dyer, \& King, 2001). As such, the topic of retention and persistence is a common subject for many researchers - the majority of which use Tinto's (1993) theory of student departure for guidance (DeAngelo, 2014). The results of several studies have indicated that students' scores on the Scholastic Aptitude Test (SAT) and the American College Testing (ACT) test have been valuable indicators of student retention and graduation in higher education (Astin, Korn, \& Green, 1987; Tross, Harper, Osher, \& Kneidinger, 2000). However, these scores cannot actively be modified once students have entered higher education; thus, administrators and professors turn to influenceable factors that aid in student retention to boost those rates.

Key factors for student retention in higher education institutions include academic performance (e.g., grades), personal commitment (e.g., self-discipline, confidence), and motivation from sources external to higher education, such as parents and community support (Moreira, Dias, Machado Vaz, \& Machado Vaz, 2012; Tinto, 2001). Researchers also have acknowledged that supportive interactions with both faculty and peers, indicating student engagement, have a positive influence on retention rates among second-year students in higher education (Morrow \& Ackermann, 2012). Moreover, researchers have observed that mentoring programs have a positive effect on students' retention and success in their academic endeavors, citing their importance in the acquisition of new and enhancement of pre-existing study skills as the reasons for the academic improvement (Scott \& Homant, 2007). Although few scholars discount the importance of academic skills (i.e., study skills) on retention rates, some researchers argue that there are factors (e.g., socio-economic status, familial support) that have greater influence on a student's persistence and retention in higher education (Moreira et al., 2012). However, most of these new factors are beyond the control 
of universities (e.g., parents, socio-economic status), and, as such, are bypassed in favor of those factors that can be influenced directly (e.g., student engagement, mentoring, study skills; DeAngelo, 2014).

\section{Graduation Rates}

State and federal agencies have placed an emphasis on increased accountability for both colleges and universities (Dill, 1999). The importance of a college education has never been greater, and the costs associated with obtaining one also have never been higher (Gonzalez \& O'Sullivan, 2010). Policy makers have explored various student outcomes as a measure of quality associated with postsecondary education (Cook \& Pullaro, 2010). Of these, graduation rates as an outcome measurement has received the most attention (Hazelkorn, 2011).

Graduation rates have become an increasingly important and scrutinized measure since President Obama stated that by 2020, the United States should once again have the highest proportion of college graduates in the world (Johnson, 2010). Seemingly, every new initiative, research report, and news story concerning college students focuses on graduation rates. For example, a 2006 report from the U.S. Secretary of Education's Commission on the Future of Higher Education posited that higher education needed to make dramatic changes on improving the persistent gap between college attendance and graduation rates of low-income students and their more affluent peers (Spellings, 2006). The U.S. Secretary of Education's Commission certainly was not the first to place an impetus on graduation rates of students in institutions of higher education, but it aided in moving the conversation that previously had been focused on input methods (i.e., access and enrollment) to output methods (i.e., persistence and graduation rates) (Spellings, 2006). This shift in education focus has led to the creation of legislation that has concentrated increasingly on institutional accountability and better consumer information (Cook \& Hartle, 2011; Cook \& Pullaro, 2010).

The American Graduation Initiative, which was proposed by President Obama and required states and colleges to establish quantifiable targets for improving graduation rates as a prerequisite for federal funding, was an example of this move for increased institutional accountability (Obama, 2009). The Higher Education Opportunity Act (HEOA, 2009), which focused on an increased disclosure of institutional graduation rates for consumer information, was another instance of federal pressure on higher education institutions. In addition, in 2009, the American Enterprise Institute produced a report stating that graduation rates convey important information and were the first step to the inquiry about college success (Hess, Schneider, Carey, \& Kelly, 2009). In 2011, Maguire Associates, in their annual report on students' common metrics, declared that high school seniors chose graduation rates as the fifth most important indicator of institutional effectiveness among 23 different criteria. In particular, they chose graduation rates before graduate school placement, rigorous core curriculum, honors programs, and the college's rank in the U.S. News \& World Report. Furthermore, both the Complete College America Alliance of States, in which 17 states have become a member, and the National Governors Association and its Compete to Complete Initiative are both focused on increasing collegiate matriculation through graduation (Nelson, 
2010; Reyna, 2010).

\section{Performance-Based Funding}

States are faced with an increasing demand for taxpayer money (e.g., healthcare costs, prison costs, education reforms, aging infrastructures), which is forcing many states to decrease funding of some endeavors and to restructure funding procedures (Dougherty, Natow, Bork, Jones, \& Vega, 2013). This includes processes for funding higher education. Seen as an equitable manner in which to fund education, performance-based funding was an idea born out of states' need to allocate limited funds in a manner that not only returned taxpayer investments concerning college access, but also as a method of promoting college completion (Burke \& Modarresi, 2000). Further, Dougherty and Reddy (2011) articulated performance-based funding as a method by which a state allocates a percentage of the budget designated for higher education by a system that measures a university's performance on specific measures (e.g., course completion, credit attainment, degree completion, increasing enrollment of underrepresented populations, job placement), allowing for universities that perform better to receive more money.

Multiple states have created unique metrics for rewarding institutions that increase the enrollment and degree completion of underrepresented populations, often defined as those students who are deemed at risk academically or economically (Jones, 2013). States also are finding ways not only to reward progress, but also to increase degree completion (Perna, Klein, \& McLendon, 2014). States that participate in performance-based funding often find that it is difficult to reward degree completion initially because it is a cumulative metric; thus, states reward progress because it helps students make step-by-step progress (Perna et al., 2014). For example, Tennessee rewards public institutions based on the number of students who complete 24, 48, and 72 credits. Ohio and Nevada place an increased weight (i.e., reward) on the number of credits that are completed at upper division (National Conference of State Legislatures, 2013).

Advocates for performance-based funding claim that research exists that supports not only basing institutional academic funding on the academic performance of students but also that this funding structure has a positive effect on both students' academics and institutional performance (Callaway, 2012). However, some researchers argue that scant data exist to support the claims that performance-based funding forces higher education institutions to increase their retention rates and graduations rates; to the contrary, performance-based funding actually might cause some schools to deteriorate (Burke, 2002; Dougherty \& Hong, 2006; Harnisch, 2011; Shin, 2009). Despite these conflicting reports, performance-based funding is a reality with which educational institutions must contend. As such, administrators must modify their programs to accommodate these changes.

\section{Summary}

Study skills have been a source of interest for educators for more than a century (Moore et al., 1983; Richardson et al., 2010). Numerous researchers have written studies supporting the 
positive relationship between study skills and GPA in academic environments (Kartika, 2007; Proctor et al., 2006; Robyak, 1978; Sanoff, 2006; Urciuoli \& Bluestone, 2013). However, the relationship between study skills and retention rates only recently has become a topic of interest (Al-Hilawani \& Sartawi, 1997; Crede \& Kuncel, 2008; Kartika, 2007; Urciuoli \& Bluestone, 2013), despite the emphasis placed on retention by theorists such as Astin (1984, 1999 and Tinto (2001). Additionally, due to the increased scrutiny and publicity placed on the educational system in the United States, graduation rates have joined retention rates as an area of concern for both politicians and university administrators alike (Hazelkorn, 2011; Johnson, 2010; Spellings, 2006). This increased interest in higher education productivity (e.g., retention rates, graduation rates) has led many governmental entities in the United States to shift educational funding from traditional methods to that of performance-based funding (Burke, 2002; Dougherty \& Hong, 2006; Hamisch, 2011). Although the academic usefulness of performance-based funding has been called into question by some researchers (Burke, 2002; Dougherty \& Hong, 2006; Harnisch, 2011; Shin, 2009), performance-based funding is a reality with which educational institutions must contend (Burke, 2002; Dougherty \& Hong, 2006; Harnisch, 2011; McKeown-Moak, 2013).

\section{Method}

\section{Selection of Participants}

Participants for this study were students from a large, public, Texas university. Students who participated in the university's formal 6-week study skills program formed the experimental group $(n=2,074)$. Using a stratified sampling method based upon student classification, the control group $(n=2,074)$ was identified from the total undergraduate population for the university for the 2004-2010 academic years ( $n=95,001$, excluding the experimental group). Data collected included program participation, in the form of attendance, and GPA. Additionally, the program participants were monitored in order to determine 1-year retention rates (i.e., returned the next academic school year [fall to fall]) and graduation rates (i.e., whether the student did or did not graduate from the university). Sampling for the study was undertaken differently for the experimental group and the control group. Study skills program participants (i.e., experimental group) were gathered via convenience sampling. In order to create a representative control group, the proportionate stratified random sampling method was applied by identifying a comparable group of students based on proportionate classifications (i.e., freshmen, sophomores, juniors, seniors) within the university population based upon the equivalent numbers of the study skills participants (i.e., intervention) (Johnson \& Christensen, 2012).

\section{Instruments}

This quantitative research study examined the difference in GPA, retention rates, and graduation rates as a function of study skills program participation. Archived data, in the form of a database, which included program participation data as well as university demographic data, were gathered from the participatory university's registrar's office and 
Institutional Effectiveness Office for the years 2004 to 2010. The data examined were from undergraduate students (i.e., experimental group), freshmen through seniors, who participated in the 6-week study skills program and from the university's overall population that represented the nonparticipants (i.e., control group) for the study.

\section{Procedures}

Approval for this study was obtained from the Institutional Review Board (IRB) at the institution where the study took place. After obtaining approval, the registrar's office, via the Institutional Effectiveness Office, released the data, which then were inputted into SPSS Statistics (Version 22). The data included information on the two groups of undergraduate students: those students who participated in the study skills program during the 2004-2010 period (i.e., experimental group; $n=2,074)$ and those students who did not $(n=95,001)$. A proportionate stratified random sample technique was employed, whereby the frequency of the study skills participants' undergraduate classification was identified via SPSS and then a proportionate sample of non-participants was randomly selected, thereby allowing for the identification of a control group $(n=2,074)$. Students who participated in the study skills program were students enrolled in the university, representing all undergraduate classifications (i.e., freshmen, sophomores, juniors, seniors). The participants were expected to complete a series of six, 50-minute study skills sessions over the span of 6 weeks, meeting only once per week. The study skills sessions encompassed a variety of information related to academic success (e.g., test-taking techniques, time management skills, note-taking methods). Only students who actually participated in the study skills program (i.e., completed at least one session) were included in the experimental group.

In an attempt to protect the confidentiality of research participants, data that could potentially identify students (e.g., names, university IDs) were excluded from the research. Additionally, either participants signed waivers granting the university permission to use their study skills program data or their data were excluded from the study's data set. As such, the university's policies (e.g., Institutional Review Board) as well as the students' rights to privacy, as outlined by the Family Education Rights and Privacy Act (2010), were acknowledged and upheld.

\section{Analysis}

In addressing the research questions, two types of analytical tests were performed. First, due to the categorical nature of study skills participation (i.e., participant/non-participant) and the continuous but non-normal scale of GPA, a nonparametric independent samples $t$ test was conducted. A 5\% level of statistical significance was used and the effect size was reported and interpreted for the statistically significant finding. To facilitate the data analysis, Version 22 of the Statistical Package for Social Sciences (SPSS) was used to address the research questions and to test the hypotheses (Field, 2013).

Due to the categorical nature of the retention and graduation variables (i.e., retention rates $=$ retained/not retained; graduation rates = graduated/not graduated) and the program participation variable (i.e., participant/non-participant), chi-square tests were performed to 
examine differences in retention rates and graduation rates as a function of program participation (i.e., participant/non-participant). In both cases, study skills program participation was the independent variable. For the independent samples $t$ test, GPA was the dependent variable, whereas the retention rates and graduation rates were the dependent variables for the chi-square tests. A Bonferroni adjustment was conducted to control for Type I error, providing an adjusted level of statistical significance of $2.5 \%$ for both chi-square tests. Effect sizes were reported and interpreted for all statistically significant findings.

\section{Results}

When addressing the research questions concerning the difference in GPA as a function of program participation, a histogram (not presented) pertaining to GPA Change, as identified by the difference between the beginning of the semester GPA and the end of semester GPA, indicated a serious departure from normality. Further, the standardized skewness coefficient (i.e., skewness coefficient divided by the standard error of skewness $=18.53$ ) and standardized kurtosis coefficient (i.e., kurtosis coefficient divided by the standard error of kurtosis $=47.38$ ) were calculated, indicating a positive skew and a leptokurtic distribution, which was extremely far outside the range of normality: -3.00 and 3.00 (Onwuegbuzie \& Daniel, 2002). As such, a nonparametric independent samples paired $t$ test (i.e., Mann-Whitney $U$ ) was conducted.

According to the Mann-Whitney $U$ test, GPA Change was statistically significant $(U=$ $345277.50, p<.0001)$. The effect size of GPA Change (0.73) indicated a moderate-to-large difference (Cohen, 1988). Therefore, students who participated in the formal study skills program exhibited a greater positive change in their GPAs than did those students who did not participate. Indeed, whereas students who did not participate in the formal study skills program, on average, experienced a slight negative decrease in their GPAs, those who did participate in this program experienced a positive increase in their GPAs. Table 1 presents the sample sizes, means, and standard deviations related to GPA Change as a function of study skills program participation.

Table 1. Number, Mean, and Standard Deviation for GPA Change by Program Participation

\begin{tabular}{lcccccc}
\hline & & & & \multicolumn{3}{c}{ Non-Participant in Study } \\
& \multicolumn{3}{c}{ Participant in Study Skills } & \multicolumn{3}{c}{ Skills } \\
\cline { 2 - 7 } Variable & $n$ & $M$ & $S D$ & $n$ & $M$ & $S D$ \\
\hline GPA Change & 1168 & 0.21 & 0.36 & 1058 & -0.03 & 0.30 \\
\hline
\end{tabular}

When analyzing the difference in retention rates between students who participated in the study skills program and those who did not, a proportionate stratified sampling method was applied by random sampling the overall population, minus the study skills participants, by student classification (i.e., freshman, sophomore, junior, senor). As such, the number of students who participated in the study skills program $(n=2,074)$ was equivalent in number to those students who did not participate $(n=2,074)$, for a total of 4,148 undergraduate students. Additionally, both the retention rates (i.e.; $n=2,966$ retained, $n=1,182$ not 
retained) and graduation rates (i.e., $n=1,590$ graduated, $n=2,558$ not graduated) mirrored the overall sample size (i.e., $N=4,148$ ). Therefore, each participant contributed to only one cell that, in addition to the categorical nature of the variables, justified the use of a chi-square test.

In order to determine the level of statistical significance, the nominal Type I error rate (i.e., $\alpha$ ) of $5 \%$ was adjusted via the Bonferroni adjustment to account for the inclusion of multiple hypothesis tests (e.g., Chandler, 1995; Ho, 2006; Manly, 2004; Vogt, 2005). This adjustment prevents an overall experiment error rate greater than $5 \%$ from occurring by dividing the nominal $\alpha$-level by the number of chi-square tests conducted (i.e., .05 / $2=.025$ ). Therefore, the adjusted $\alpha$-level was .025 when identifying the level of statistical significance regarding the relationships between study skills program participation and retention rates and graduation rates.

A 2 (program participation) x 2 (1-year retention rates) chi-square analysis was performed to examine the difference in 1-year retention rates (i.e., retained from fall to fall semester) between students in the experimental group and the control group. After implementing the Bonferroni adjustment, this analysis did not reveal a statistically significant relationship (i.e., $\chi^{2}[1, N=4,148]=.08, p=.78$ ); as such, no effect size was calculated (Robinson \& Levin, 1997). In particular, the compositional breakdown of the two study skills program participation categories were as follows: (a) $71.70 \%$ of the students who participated in the program were retained and $28.30 \%$ were not; and (b) $71.31 \%$ of the students who did not participate in the program were retained and $28.69 \%$ were not.

Finally, a 2 (program participation) x 2 (graduation rates) chi-square analysis also was performed to examine the difference in graduation rates (i.e., did the student graduate or not) between students in the experimental group and the control group. After implementing the Bonferroni adjustment, this analysis revealed a statistically significant difference (i.e., $\chi^{2}[1$, $N=4148]=16.71, p<.0001)$. However, the effect size associated with this difference, as measured by Cramer's $V$ (i.e., .004), was practically nonexistent (Cohen, 1988). In particular, the compositional breakdown of the two study skills program participation categories were as follows: (a) $35.25 \%$ of the students who participated in the program graduated and $64.75 \%$ did not; and (b) $41.42 \%$ of the students who did not participate in the program graduated and $58.58 \%$ did not.

\section{Discussion}

Previous studies have supported the assertion that there is a relationship between study skills program participation and GPA as well as between study skills program participation and retention rates (Kartika, 2007; Proctor et al., 2006; Robyak, 1978; Sanoff, 2006; Urciuoli \& Bluestone, 2013); however, researchers have not examined the relationship between study skills participation and graduation rates. The findings of this study confirmed the hypothesis that there is a relationship between GPA and study skills program participation, as supported by the statistically significant findings $(U=345277.50, p<.0001)$ as well as the 
moderate-to-large effect size (0.73). This, in turn, supports the theories of both Astin (1984, 1999) and Tinto $(1993,2001)$ concerning the positive influence of academic support on student success.

However, the results of this study concerning the effect of study skills participation on retention rates, although not negative, were not positive either, as evidenced by the lack of statistical significance. This finding differed from the results of Kartika (2007) and Urciuoli and Bluestone (2013), which revealed a positive relationship between study skills and retention rates. Several reasons might account for why this finding did not support previous findings. In particular, the proportionate stratified random sampling method might have randomly assigned students who possessed retention rates that were lower than was the norm to the control group, thereby accounting for the lack of support for previous studies. It is important to note that, although the results of this study did not verify a positive relationship between study skills participation and retention, other researchers have documented this relationship (Kartika, 2007; Proctor et al., 2006; Robyak, 1978; Sanoff, 2006; Urciuoli \& Bluestone, 2013). As such, this one study should not be used to negate the importance of study skills participation to retention rates.

The chi-square analysis concerning study skills participation and graduation rates indicated a statistically significant relationship between the two variables. However, according to Cohen's (1988) criteria, the effect size was so small that it was practically nonexistent, thereby calling into question the strength of the connection between these variables (Kelley \& Preacher, 2012). It would be worthwhile to conduct further studies analyzing the relationship between study skills participation and graduation.

\section{Limitations}

A limitation of the findings stems from the restriction of this study to only one school in a single geographic location, which could limit the application of the data across multiple institutions in different environs. Additionally, caution always should be exercised when interpreting the findings from causal-comparative research due to the numerous confounding variables that might unduly influence effect sizes (Onwuegbuzie, 2003). Moreover, researchers should be cautious when interpreting the results from studies using a causal-comparative design because the independent variable already occurred; thus, causality, could not necessarily be inferred (Creswell, 2008). Furthermore, there is no way to control the independent variable when using archived data. As with any research study in education, the result validity might be jeopardized by interaction effects (e.g., health, initial preparation, emotional state) and sampling errors (e.g., the use of comparative populations for comparison instead of the entire population).

Another limitation of the study was the mode of participation in the study skills program. Students who participated in the study skills program either were self-selected or were required to participate in the program as a form of remediation after having been placed on academic probation or readmitted to the university after readmission post-suspension, thereby causing a threat to external validity in the form of multiple-treatment interference (Onwuegbuzie, 2003). Additionally, several instructors presented the study skills material 
over the 6 years studied, thereby introducing the potential for implementation bias, where instructors present the information in different ways, which can dversely affect the internal validity of the findings (Onwuegbuzie, 2003).

The student participant's history also could be a threat to the internal validity of the findings (Onwuegbuzie, 2003). The presence of prior academic difficulties could have potentially affected, either positively or negatively, the data concerning GPA, retention rates, and graduation rates. In addition, research conducted on educational performance always can be affected by outside factors such as parental support, peer influence, socioeconomic status, and student motivation (Tinto, 1993, 2001). These changes to a student's environment can either negatively or positively affect a student's academic performance, thereby leading to results attributed to a variety of interventions (e.g., study skills programs), again threatening the internal validity of the findings.

\section{Recommendations}

The focus of this research study was on the influence of study skills participation on GPA, retention rates, and graduation rates. This research was necessary due to the limited number of studies focused on the effect of study skills on retention rates and the lack of research readily available concerning its relationship to graduation rates. The findings of this study corroborated the findings of previous research concerning GPA (Al-Hilawani \& Sartawi, 1997; Crede \& Kuncel, 2008; Kartika, 2007); however, due to the inconclusive results concerning the influence of study skills participation on both retention rates and graduation rates (i.e., statistical non-significance and extremely small effect size, respectively), further studies should be conducted. Moreover, when conducting new research into the topic of study skills, ideally, participatory groups should either be randomized or be compared to like groups within the overall population. This would reduce sampling error and provide more meaningful insights into the effectiveness of study skills participation.

The findings from this study did corroborate previous research concerning the positive influence of study skills on students' academic performance in the form of GPA (Al-Hilawani \& Sartawi, 1997; Crede \& Kuncel, 2008; Kartika, 2007). Contrastingly, the findings of this study did not suggest a relationship between study skills program participation and retention rates and graduation rates. As such, with increasing pressure from policy makers who demand improvements in student and university success rates (e.g., retention rates, graduation rates), higher education administrators and researchers should continue to study the relationship between study skills program participation and retention rates and graduation rates in order to establish more adequately a more comprehensive view of the relationship between study skills and academic success. 


\section{References}

Abel, D. (2000, May 17). Going backwards: US falls behind in college graduation rate. The Boston Globe. Retrieved from http://www.bostonglobe.com

Al-Hilawani, Y. A., \& Sartawi, A. A. (1997). Study skills and habits of female university students. College Student Journal, 31, 537-544.

Astin, A.W. (1984). Student involvement: A developmental theory for higher education. Journal of College Student Development, 25, 297-308.

Astin, A.W. (1999). Involvement in learning revisited: Lessons we have learned. Journal of College Student Development, 40, 587-598.

Astin, A. W., Korn, W., \& Green, K. (1987). Retaining and satisfying students. Educational Record, 68, 36-42.

Burke, J. C. (Ed.). (2002). Funding public colleges and universities for performance: Popularity, problems, and prospects. Albany, NY: Rockefeller Institute Press.

Burke, J. C., \& Modarresi, S. (2000). To keep or not to keep performance based funding: Signals from stakeholders. The Journal of Higher Education, 71, 432-453. Retrieved from http://www.jstor.org/stable/2649147

Callaway, C. (2012). When success pays: Lessons learned from Arkansas' move to performance-based funding. Community College Journal, 82(4), 29-31.

Chalian, D. (2012, June 20). Obama education chief: Complacency caused United States to slip to 16th in world college graduation rates [Web log comment]. Retrieved from http:/finance.yahoo.com/blogs/daily-ticker/obama-educationchief-u-complacency-cause d-United States-to-slip-to-16th-in-world-college-graduation-rates.html

Chandler, C. R. (1995). Practical considerations in the use of simultaneous inference for $\begin{array}{llll}\text { multiple } & \text { tests. } & \text { Animal }\end{array}$ http://dx.doi.org/10.1006/anbe.1995.0069

Cohen, J. (1988). Statistical power analysis for the behavioral sciences (2nd ed.). Hillsdale, NJ: Lawrence Erlbaum.

Cook, B., \& Hartle, T. W. (2011, Spring/Summer). Why graduation rates matter - and why they don't. American Council on Education. Retrieved from http://www.acenet.edu/the-presidency/columns-and-features/Pages/Why-Graduation-Rat es-Matter $\%$ E2\%80\%94and-Why-They-Don $\%$ E2\%80\%99t.aspx

Cook, B., \& Pullaro, N. (2010). College graduation rates: Behind the numbers. Washington, DC: American Council on Education.

Crede, M., \& Kuncel, N. (2008). Study habits, skills, and attitudes: The third pillar supporting collegiate academic performance. Perspective on Psychological Science, 3, 425-453. http://dx.doi.org/10.1111=j.1745-6924.2008.00089.x 
Creswell, J. W. (2008). Educational research: Planning, conducting, and evaluation quantitative and qualitative research (3rd ed.). Upper Saddle River, NJ: Pearson Prentice Hall.

DeAngelo, L. (2014). Programs and practices that retain students from the first to second year: Results from a national study. New Directions for Institutional Research, 160, 53-75. http://dx.doi.org/10.1002/ir.20061

Dill, D. (1999). Academic accountability and university adaptation: The architecture of an academic learning organization. Higher Education, 38, 127-154.

Dougherty, K. J., \& Hong, E. (2006). Performance accountability as imperfect panacea: The community college experience. In T. Bailey \& V. S. Morest (Eds.), Defending the community college equity agenda (pp. 51-86). Baltimore, MD: Johns Hopkins University Press.

Dougherty, K. J., Natow, R. S., Bork, R. H., Jones, S. M., \& Vega, B. E. (2013). Accounting for higher education accountability: Political origins of state performance funding for higher education. Teacher College Record, 115, 1-50.

Dougherty, K. J., \& Reddy, V. (2011). The impacts of state performance funding systems on higher education institutions: Research literature review and policy recommendations. Community College Research Center Working Paper No. 37, Columbia University, New York, NY.

Eveland, W. P., \& Dunwoody, S. (2002). An investigation of elaboration and selective scanning as mediators of learning from the web versus print. Journal of Broadcasting and Electronic Media, 46(1), 34-54. http://dx.doi.org/10.1207/s15506878jobem4601_3

Family Educational Rights and Privacy Act, 20 U.S.C. § 1232g; 34 CFR Part 99 (2010).

Field, A. (2013). Discovering statistics using IBM SPSS statistics (4th ed.). Thousand Oaks, CA: Sage.

Gardner, K. (1979). Summary and conclusions. In E. Lunzer \& K. Gardner (Eds.), The effective use of reading (pp. 299-313). London, England: Heinemann Educational Books, Ltd.

Garton, B. L., Dyer, J. E., \& King, B. O. (2001). Factors associated with the academic performance and retention in college introductory courses. National Association of Colleges and Teachers of Agriculture Journal, 48(3), 14-18.

Gettinger, M., \& Seibert, J. K. (2002). Contributions of study skills to academic competence. School Psychology Review, 43, 350-366.

Gonzalez, A., \& O'Sullivan, C. (2010). Why is college so expensive? National Center for Policy Analysis (Brief analysis 726). Retrieved from http://www.ncpa.org/pdfs/ba726.pdf

Harnisch, T. (2011). Performance-based funding: A re-emerging strategy in public higher 
education financing (Higher Education Policy Brief). Washington, DC: American Association of State Colleges and Universities.

Harris, T. L., \& Hodges, R. E. (1995). The literacy dictionary: The vocabulary of reading and writing. Newark, DE: International Reading Association.

Hazelkorn, E. (2011). Rankings and the reshaping of higher education: The battle for world-class excellence. Houndsmill, England: Palgrave-Macmillan.

Hess, F. M., Schneider, M., Carey, K., \& Kelly, A. P. (2009). Diplomas and dropouts: Which colleges actually graduate their students (and which don't). Washington, DC: American Enterprise Institute for Public Policy Research.

Higher Education Opportunity Act, Pub. L. No. 110-315, § 766-767, Stat. 3365, 3366 (2009).

Ho, R. (2006). Handbook of univariate and multivariate data analysis and interpretation with SPSS. London, England: Chapman \& Hall.

Johnson, R. B., \& Christensen, L. (2012). Educational research: Quantitative, qualitative, and mixed approaches (4th ed.). Thousand Oaks, CA: Sage.

Johnson, J. (2010, December 8). International education rankings suggest reform can lift United States [Web log comment]. Retrieved from http://www.ed.gov/blog/2010/12/international-education-rankings-suggest-reform-can-li ft-u-s/

Jones, D. P. (2013, October). Outcomes-based funding: The wave of implementation. Washington, DC: Complete College American and National Center for Higher Education Management Systems.

Kartika, A. (2007). Study skills training: Is it an answer to the lack of college students' study skills? International Journal of Learning, 14(9), 35-43.

Kelley, K., \& Preacher, K. J. (2012). On effect size. Psychological Methods, 17, 137-152. http://dx.doi.org/10.1037/a0028086

Knowles, M. S. (1975). Self-directed learning: A guide for learners and teachers. Englewood Cliffs, NJ: Prentice Hall.

Larose, S., \& Roy, R. (1991). The role of prior academic performance and nonacademic attributes in the prediction of the success of high risk college students. Journal of College Student Development, 32, 171-177.

Lenz, B. E., Ellis, E. S., \& Scanlon, D. (1996). Teaching learning strategies to adolescents and adults with learning disabilities. Austin, TX: Pro-Ed.

Maguire Associates. (2011). Students' college preferences and plans in the 2011 admissions cycle: Results from the 2011 College Decision Impact Survey. Concord, MA: Maguire Associates \& Fastweb.

Manly, B. F. J. (2004). Multivariate statistical methods: A primer (3rd ed.). London, England: 
Chapman \& Hall.

McKeown-Moak, M. P. (2013). The "new" performance funding in higher education. Educational Considerations, 40(2), 3-12.

Metzner, B., \& Bean, J. P. (1987). The estimation of a conceptual model for nontraditional undergraduate student attrition. Research in Higher Education, 27(1), 15-38. http://dx.doi.org/10.1007/BF00992303

Moore, D. W., Readance, J. E., \& Rickelman, R. J. (1983). An historical exploration of content area reading instruction. Reading Research Quarterly, 18, 419-438. http://dx.doi.org/10.2307/747377

Moreira, P. A. S., Dias, P., Machado Vaz, F., \& Machado Vaz, J. (2012). Predictors of academic performance and school engagement - Integrating persistence, motivation and study skills perspectives using person-centered and variable-centered approaches. Learning and Individual Difference, 24, 117-125. http://dx.doi.org/10.1016/j.lindif.2012.10.016

Morrow, J. A., \& Ackermann, M. (2012). Intention to persist and retention of first-year students: The importance of motivation and sense of belonging. College Student Journal, 46, 483-491.

National Conference of State Legislatures. (2013). Performance funding for higher education. Retrieved from http://www.ncsl.org/issues-research/educ/performance-funding.aspx

Nelson, L. (2010, March 2). 17 states pledge to increase graduation rates, joining a new national effort. The Chronicle of Higher Education. Retrieved from http://www.chronicle.com

Nicaise, M., \& Gettinger, M. (1995). Fostering reading comprehension in college students. Reading Psychology, 16, 283-337. http://dx.doi.org/10.1080/0270271950160302

Obama, B. (2009, July 14). Remarks by the president on the American Graduation Initiative. Washington, DC: The White House, Office of the Press Secretary.

Onwuegbuzie, A. J. (2003). Expanding the framework of internal and external validity in quantitative research. Research in the Schools, 10(1), 71-90.

Onwuegbuzie, A. J., \& Daniel, L. G. (2002). Uses and misuses of the correlation coefficient. Research in the Schools, 9(1), 73-90.

Perna, L. W., Klein, M. W., \& McLendon, M. K. (2014). Insights and implications for state policy-makers. The ANNALS of the American Academy of Political and Social Science, 655, 209-230. http://dx.doi.org/10.1177/0002716214539895

Proctor, B. E., Prevatt, F. F., Adams, K. S., \& Reaser, A. (2006). Study skills profiles of normal-achieving and academically-struggling college students. Journal of College Student Development, 47(1), 37-51. http://dx.doi.org/10.1353/csd.2006.0011 
Reyna, R. (Ed.). (2010). Compete to complete: Common college completion metrics. Washington, D.C.: National Governors Association.

Richards, C. S. (1975). Behavior modification of studying through study skills advice and self-control procedures. Journal of Counseling Psychology, 22, 431-435. http://dx.doi.org/10.1037/h0077151

Richardson, J. S., Robnolt, V. J., \& Rhodes, J. A. (2010). A history of study skills: Not hot, but not forgotten. Reading Improvement, 47, 111-123.

Robinson, D. H., \& Levin, J. R. (1997). Reflections on statistical and substantive significance, with a slice of replication. Educational Researcher, 26(5), 21-26. http://dx.doi.org/10.2307/1176544

Robyak, J. (1978). Study skills versus non-study skills students: A discriminant analysis. The Journal of Education Research, 71, 161-166. http://dx.doi.org/10.1080/00220671.1978.10885061

Sanoff, A. P. (2006, March 10). A perception gap over students' preparation. The Chronicle of Higher Education. Retrieved from http://chronicle.com/section/Home/5

Scott, C. L., \& Homant, R. J. (2007). The professional mentor program plus: An academic success and retention tool for adult learners. Journal of College Student Retention: $\begin{array}{lllll}\text { Research, } \quad \text { Theory } \quad \text { Practice, } & 9(1),\end{array}$ http://dx.doi.org/10.2190/D370-4767-PT35-47U8

Shin, J. C. (2009). Impacts of performance-based accountability on institutional performance in the U.S. The International Journal of Higher Education and Educational Planning, 60(1), 47-68. http://dx.doi.org/10.1007/s10734-009-9285-y

Spellings, M. (2006). A test of leadership: Charting the future of U.S. higher education. Washington, D.C.: US Department of Education.

Tierney, R. J., \& Cunningham, J. W. (1980). Research on teaching reading comprehension (Tech. Rep. No. 187). Urbana, IL: University of Illinois, Center for the Study of Reading.

Tinto, V. (1993). Leaving college: Rethinking the causes and cures of student attrition $\left(^{\text {nd }}\right.$ ed.). Chicago, IL: University of Chicago Press.

Tinto, V. (2001). Rethinking the first year of college: Higher Education Monograph Series. New York, NY: Syracuse University.

Tross, S. A., Harper, J. P., Osher, L. W., \& Kneidinger, L. M. (2000). Not the usual cast of characteristics: Using personality to predict college performance and retention. Journal of College Student Development, 4, 323-334.

Urciuoli, J. A., \& Bluestone, C. (2013). Study skills analysis: A pilot study linking a success and psychology course. Community College Journal of Research and Practice, 37, 397-401. http://dx.doi.org/10.1080/10668926.2012.716386 


\section{Macrothink}

International Journal of Education

ISSN 1948-5476

2015, Vol. 7, No. 1

Vogt, W. P. (2005). Dictionary of statistics and methodology: A nontechnical guide for the social sciences (3rd ed.). Thousand Oaks, CA: Sage.

\section{Copyright Disclaimer}

Copyright for this article is retained by the author(s), with first publication rights granted to the journal.

This is an open-access article distributed under the terms and conditions of the Creative Commons Attribution license (http://creativecommons.org/licenses/by/3.0/). 